\title{
MPO wt Allele
}

National Cancer Institute

\section{Source}

National Cancer Institute. MPO wt Allele. NCI Thesaurus. Code C91743.

Human MPO wild-type allele is located in the vicinity of $17 q 23.1$ and is approximately 11

$\mathrm{kb}$ in length. This allele, which encodes myeloperoxidase protein, plays a role in the mediation of hypohalous acid production. 